\title{
Evaluation of antioxidant, anti-hemolytic, cytotoxic effects and anti-bacterial activity of selected mangrove plants (Bruguiera gymnorrhiza and Heritiera littoralis) in Bangladesh
}

Md. Adnan Karim¹, Md. Aminul Islam, Md. Muzahidul Islam¹, Md. Saidur Rahman', Sharmin Sultana', Satyajit Biswas ${ }^{1}$, Mohammad Jakir Hosen², Kishor Mazumder ${ }^{3}$, Md. Masuder Rahman ${ }^{4}$ and Md. Nazmul Hasan ${ }^{1^{*}}$ (D)

\begin{abstract}
Objectives: In this present study, antioxidant, anti-hemolytic, cytotoxic and anti-bacterial activities derived from methanol extracts of Bruguiera gymnorrhiza and Heritiera littoralis were investigated in order to determine their medicinal activities.

Materials and methods: Folin-Ciocalteu reagent method and aluminum chloride methods were used to determine the mangroves' total phenolics and total flavonoid content, respectively. Antioxidant capacity was assessed via the following methods: 1,1-diphenyl-2-picryl hydroxyl (DPPH), $43 \mathrm{mM} \mathrm{H}_{2} \mathrm{O}_{2}$, Fe ${ }^{2+}$ quenching assay, and anti-hemolytic activity. Brine shrimp (Artemia salina $\mathrm{L}$.) lethality assay was also carried out to determine the cytotoxic potential of the mangroves along with antibacterial activity test using five Gram-negative and another two Gram-positive bacterial strains.
\end{abstract}

Results: The mangroves yielded $58.917 \pm 0.601$ and $36.625 \pm 0.551 \mathrm{mg}$ Gallic acid equivalent (GAE)/g sample and $76.417 \pm 0.19$ and $113.637 \pm 0.17 \mathrm{mg}$ quercetin equivalent (QE)/g sample in B. gymnorrhiza and $H$. littoralis, respectively. Methanol extracts of both mangroves exhibited high radical scavenging activity against $\mathrm{DPPH}, \mathrm{H}_{2} \mathrm{O}_{2}$ and $\mathrm{Fe}^{2+}$ radicals. The reductive capacity of the extracts increased with increasing concentrations of samples, and the extracts inhibited $\mathrm{H}_{2} \mathrm{O}_{2}$ induced hemolysis in human red blood cells (RBCS). Antioxidant properties were found to be moderately weaker than that of the reference standard, L-ascorbic acid (AA), and Gallic acid (GA). Further, brine shrimp (Artemia salina L.) lethality assay revealed significant cytotoxicity (241.4 and $272.6 \mu \mathrm{g} / \mathrm{mL}$, respectively). Methanol extracts could also inhibit the growth of pathogenic bacterial strains.

Conclusion: This study showed that the crude methanol extract of selected mangrove plants possesses free radical scavenging, anti-hemolytic, cytotoxic and anti-bacterial activity. The experimented plant has the potential to be used as a traditional medicine and replace synthetic drugs. Further studies are necessary to isolate active compounds responsible for the overall antioxidant activity of the crude extracts.

Keywords: Antioxidant, Free radical scavenging, Red blood cell hemolysis, Cytotoxicity, Anti-bacterial, Mangrove plants, Bangladesh

\footnotetext{
* Correspondence: mnhasan1978@gmail.com

${ }^{1}$ Department of Genetic Engineering and Biotechnology, Faculty of Biological

Science and Technology, Jashore University of Science and Technology,

Jashore, Bangladesh

Full list of author information is available at the end of the article
} 


\section{Introduction}

The term mangrove usually describes the assemblage of woody trees and shrubs which mainly grow in coastal saline habitats in the world's tropical and subtropical regions. Plants are an important source of potentially useful phytochemicals for the development of new chemotherapeutic agents [1]. Extracts and phytochemicals of several mangrove plant species are used extensively in folkloric medicine mostly to treat a number of diseases, for example microbial infections, cardiovascular diseases, and cancer. These compounds are also being currently used as pesticides (insecticides, herbicides, and fungicides) in agriculture [2]. According to one study, about $80 \%$ of present-day drugs are either directly or indirectly obtained from medicinal plants [3]. In most of the world's developing countries, natural plants are are deemed a precious source of natural wealth and have been incorporated in several healthcare programs. Mangrove forests are distributed among 112 countries and the global coverage of these forests is approximately 18 million hectares [4]. Leaves of mangrove plant species are rich in phenols and flavonoids that serve as ultraviolet screening compounds. Due to their significant constitution of tannin, phenol, flavonoid and other antioxidant substances, they are commonly used as folk medicines against several diseases [2].

Research on plants' antioxidant properties has garnered much importance in recent years in the field of medicine as well as in the food industry. Inherited consumption of oxygen leads to the generation of a series of reactive oxygen species (ROS) during cell growth [5]. ROS consist of super oxide anion radicals $\left(\mathrm{O}_{2}^{-}\right)$, hydroxyl radicals $\left(\mathrm{OH}^{*}\right)$ and non-free radical species like hydrogen peroxide $\left(\mathrm{H}_{2} \mathrm{O}_{2}\right)$ and singlet oxygen $\left({ }^{1} \mathrm{O}_{2}\right)$ [6]. Such oxidative species initiate peroxidation of membrane lipids, leading to the accumulation of lipid peroxides and are also responsible for aging and cell membrane disintegration, membrane protein damage, DNA mutations, and various other diseases. If scavenging by cellular constituents does not occur effectively on ROS then it may lead to diseased conditions. ROS, however, also represent an important anti-microbial host defense mechanism of plants and animals against pathogens, e.g. a defense mechanism against Salmonella enterica and Staphylococcus aureus $[7,8]$. Consequently, it is important to maintain a balanced state of ROS in order to maintain a host defense mechanism while using plant crude extracts for therapeutic purposes.

The most important components of medicinal plants are phenolics, tannins, flavonoids and alkaloids [9]. Both edible and non-edible plants consist of phenolic compounds and they have been reported to create different biological outcomes. Phenols and flavonoids exhibit a preventive role in the development of cancer and cardiac diseases [10]. At present, the antioxidants that are widely available comprise butylated hydroxyanisole (BHA), butylated hydroxytoluene ((BHT), propyl gallate and tertbutyl hydroquinone. Of these four commercially available antioxidants, BHA and BHT have aroused suspicions of being responsible for pancreatic damage and carcinogenesis. This situation has led to the growing interest in natural antioxidants [11-14]. Despite being the main constituent of several medicinal properties, plants are also noted for their toxicity [15]. In such cases, brine shrimp (Artemia salina L.) cytotoxicity assays have been conducted to determine the pharmacological activity and toxicity of medicinal plants [16]. The cytotoxicity assay based on brine shrimp lethality was considered an essential part of preliminary toxicity assessment [17].

Due to the saline nature of mangrove soil, mangrove plants usually grow differently, subsequently resulting in variations in their vegetation, species composition, and structure in the global, regional and local contexts $[18,19]$. The soil of the mangrove forest acts as a reservoir of carbon that interacts with the atmosphere, storing about three times the biomass that makes up the vegetation and structure of mangroves [20]. The $\mathrm{pH}$ of mangrove soil significantly affects the composition of inhabitant species, primarily due to the change in availability of both essential elements such as Phosphorus (P), as well as non-essential elements [21, 22]. Analyses have detected significant correlations between the variation in soil structure with soil physico-chemical characteristics and particularly with differences in salinity levels [23]; soil $\mathrm{NO}_{3}$, especially the nitrate to phosphate ratio, soil moisture content and soil temperature [24]. Most investigations of nutrient limitations to mangrove swamps have focused on macronutrients $\mathrm{N}$ and $\mathrm{P}$, which most likely limit the structure and productivity of mangroves [25]. In mangrove soils, $\mathrm{N}$ was considered the primary nutrient that affects species composition and forest structure, although more recent analysis found that $\mathrm{N}$ and $\mathrm{P}$ influence structure and composition in approximately equal proportions [26]. A more recent analysis of salt stress on Schizonepeta tenuifolia Briq, showed that salt stress results in reduced plants' dry biomass. Further, the phytochemical analysis showed that the antioxidant content, including phenolics and flavonoids, increased at low $(25 \mathrm{mM})$ or moderate $(50 \mathrm{mM})$ levels. However, it declined at severe (75 and $100 \mathrm{mM})$ levels of salinity [27]. For this reason, it can be assumed that mangrove soils saline conditions wield some major effects on plants' physiology and biosynthesis.

Bruguiera gymnorrhiza (B. gymnorrhiza (L.) Lamk), also known as the large-leafed mangrove is one of the most prominent and widespread plant species in the $\mathrm{Pa}$ cific region. It,mostly grows in the intertidal regions ranging from Southeast Asian coastlines to Japan's Ryukyu Island [28]. Heritiera littoralis (locally known as "Sundari" in Bangladesh) is another mangrove plants species 
with an appreciable economic value. Leaves, stems, and seeds of $H$. littoralis are widely used in the treatment of diarrhea, dysentery, stomach aches and traditionally for controlling mosquitoes [2, 29-31]. In Bangladesh, this plant species is highly abundant in the southern region of Sundarbans, the largest mangrove forest of Southeast Asia. It is a mangrove area in the delta formed by the confluence of the Ganges, Brahmaputra and Meghna Rivers in the Bay of Bengal. Its geographical location is Longitude: $22.4281^{\circ} \mathrm{N}$, Latitude: $89.5888^{\circ} \mathrm{E}$. Several studies have suggested the medicinal uses of B. gymnorrhiza. The fruits have been used for the treatment of diarrhea, shingles and eye diseases [29, 32, 33]. The bark has also been used as an astringent treatment of diarrhea and malaria [32, 33]. The roots and leaves have been used to treat burn [33]. The largest amount of crude extract has been produced from B. gymnorrhiza fruits by extraction with methanol, which was $7.85 \%$. This crude extract also resulted in significant antioxidant activity [34]. H. littoralis, on the other hand, has resulted in significant biochemical compounds of flavonoid and terpenoid family as well as cinnamoylglycoflavonoid, antimycobacterial and antioxidant properties [30, 35-39]. Despite the fact that antimicrobial, antioxidant, anticancer, antihyperglycemic and antinociceptive effects of $H$. fomes have already been reported, only a few studies were carried out on $H$. littoralis [40-44].

The present study was done using methanol extracts of Bangladeshi endogenous B. gymnorrhiza and $H$. littoralis leaves to evaluate the antioxidant potential, bioactive compounds as free radical scavengers, antimicrobial and cytotoxic effects of the crude extract. It commenced with the collection and processing of samples, extraction, and biochemical assay. Reported here in great detail are the bioactive, antioxidative constituents as well as antioxidant, antimicrobial and cytotoxicity of crude extracts of two largeleafed mangrove species (B. gymnorrhiza and H. littoralis).

\section{Materials and methods}

\section{Plant material collection and preparation}

Fresh leaves of $H$. littoralis and B. gymnorrhiza were collected on 20th July 2018 from Sundarbans, Bangladesh (geographical location is Longitude: $22.4281^{\circ} \mathrm{N}$, Latitude: $89.5888^{\circ}$ E). The plants were botanically identified and confirmed by the Bangladesh National Herbarium. First, the leaves were dried in the shade for 10 days at room temperature. Then the air-dried leaves of both plants were cut into small pieces and turned into crude powder using a mechanical chopper. The crude powder was stored in appropriate containers and kept in the cold and dark to prevent fungal contamination.

\section{Extract preparation}

For the preparation of methanol extracts, about $300 \mathrm{~g}$ of air-dried powder of both plants were put into a flat bottomed glass jars and soaked in $1000 \mathrm{~mL}$ methanol (95\%). They were then sealed and kept for $72 \mathrm{~h}$ in a dark room and subjected to occasional shaking and stirring. The mixtures were filtered coarsely using Whatman filter paper. Followed by the organic filtrates obtained being evaporated utilizing a water bath at $98{ }^{\circ} \mathrm{C}$ with an electric fan until they were completely dried. The crude extracts of both $H$. littoralis and B. gymnorrhiza weighed about $3.9 \mathrm{~g}$ and $6.8 \mathrm{~g}$, respectively.

\section{Total phenolic content assay}

Polyphenols in the plant extracts react with redox reagents to form blue complex chromogens that can be detected by visible-light spectrophotometry [45]. In our study, we followed a previous method with a slight modification to determine the total phenolic content of crude extracts [46]. Gallic acid solution was diluted to five different concentrations (31.25$500 \mu \mathrm{g} / \mathrm{mL}$ ). The extract solution was prepared at a concentration of $500 \mu \mathrm{g} / \mathrm{mL}$. Extract solutions were later added with $5 \mathrm{~mL}$ of $10 \%$ Folin-Ciocalteu reagent (Scharlab S.L., Spain) followed by $4 \mathrm{~mL}$ of $7 \%$ sodium carbonate (Emplura, Merk, India). Absorbance was measured at $750 \mathrm{~nm}$ wavelength after 20 min of incubation. The standard calibration curve of Gallic acid was plotted.

$$
\begin{aligned}
& \text { Total Phenolic Content TPC, A } \\
& =(\mathrm{C} * \mathrm{~V}) / \mathrm{M}(\mathrm{mg} / \mathrm{gm})
\end{aligned}
$$

Here, $\mathrm{A}$ is the phenolic assay, $\mathrm{C}$ is the Gallic acid equivalent concentration, $\mathrm{V}$ is the volume of the extract solution used and $\mathrm{M}$ is the weight of the extract used.

\section{Total flavonoid content assay}

Total flavonoid content assay for both plants was carried out with modifications based on previous methods [47, 48]. Quercetin was used as a standard by dissolving in $\mathrm{D}_{2} \mathrm{O}$ and diluted to different concentrations $(31.25-1000 \mu \mathrm{g} / \mathrm{mL})$. Similarly, $1 \mathrm{mg} / \mathrm{mL}$ crude extract solutions were prepared. In each test tube, $0.5 \mathrm{~mL}$ of standard solutions were poured and made up to $1 \mathrm{~mL}$ by adding $\mathrm{D}_{2} \mathrm{O}$. Later the diluted solutions were mixed with $4 \mathrm{~mL}$ of distilled water, $0.3 \mathrm{~mL}$ of $5 \% \mathrm{NaNO}_{2}$ and further added with $0.3 \mathrm{~mL}$ of $10 \% \mathrm{AlCl}_{3}$ after an incubation time lasting approximately $5 \mathrm{~min}$. Then, $2 \mathrm{~mL}$ of $1 \mathrm{~mol} / \mathrm{L} \mathrm{NaOH}$ solution were added followed by added distilled water to bring the final volume to $10 \mathrm{~mL}$. This mixture was incubated at room temperature for $15 \mathrm{~min}$, and absorbance was measured at $510 \mathrm{~nm}$. The total flavonoid content was calculated from a calibration curve, and the results were expressed as $\mathrm{mg}$ 
quercetin equivalent $(\mathrm{QE}) / \mathrm{g}$ of extract. The standard calibration curve of quercetin was plotted.

$$
\begin{aligned}
& \text { Total Phenolic Content TPC, A } \\
& =(\mathrm{C} * \mathrm{~V}) / \mathrm{M}(\mathrm{mg} / \mathrm{gm})
\end{aligned}
$$

Here, $\mathrm{A}$ is the flavonoid assay, $\mathrm{C}$ is the quercetin acid equivalent concentration, $\mathrm{V}$ is the volume of the extract solution used and $\mathrm{M}$ is the weight of the extract used.

\section{DPPH radical scavenging assay}

The DPPH scavenging activity of both plant extracts was measured according to previous methods with a few modifications [49]. Sample extract and L-ascorbic acid (standard) were weighed and dissolved in 95\% methanol to make a homogenous stock solution with the highest concentration i.e. $100 \mu \mathrm{g} / \mathrm{mL}$, with the help of vortex. Then aliquots of 5 concentrations $(3.12,6.25,12.5,25$, 50 and $100 \mu \mathrm{g} / \mathrm{mL}$ ) were created through a serial dilution technique both for plant extract and L-ascorbic acid (Research lab, India), which served as a positive control. DPPH (Sigma-Aldrich, Germany) was also weighed and dissolved in $95 \%$ methanol to make $0.2 \mathrm{mM}$ solution. 2 $\mathrm{mL}$ of $0.2 \mathrm{mM}$ DPPH solution was placed by micropipette into each test tube containing $2 \mathrm{~mL}$ of sample solution. The final volume of the solution was $4 \mathrm{~mL}$. Then the test tube was retained in a dark environment for 30 min to complete the reaction. A blank test tube was also filled with DPPH with an equal volume of $95 \%$ methanol. The absorbance of each test tube was determined by UV spectrophotometer at $517 \mathrm{~nm}$.

Percentage of inhibition was calculated as-.

$$
\text { \%inhibition }=\{(\text { Ao-As }) / \text { Ao }\} * 100
$$

Here, Ao is the absorbance of positive control and As is the absorbance of the sample.

The $\mathrm{IC}_{50}$ value is the concentration of the sample required to scavenge $50 \%$ of DPPH free radical and we calculated this from the plot of \% inhibition against the log concentration of sample extract.

\section{Peroxide radical scavenging assay}

In this study, we used a prior method [50] with some modifications for our experiments. A solution of 43 $\mathrm{mM} \mathrm{H}_{2} \mathrm{O}_{2}$ was prepared in $0.1 \mathrm{M}$ phosphate buffer (pH 7.4). Both extract and standard solution were prepared at four different concentrations $(7.8125,15.625$, 31.25 and $62.5 \mu \mathrm{g} / \mathrm{mL}$ ). Sample solutions were dissolved in $3.4 \mathrm{~mL}$ of phosphate buffer and $0.6 \mathrm{~mL}$ of $\mathrm{H}_{2} \mathrm{O}_{2}$ solution $(43 \mathrm{mM})$ was added. Absorbance was measured at $230 \mathrm{~nm}$ by UV spectrophotometer. A blank was prepared using a sodium phosphate buffer without $\mathrm{H}_{2} \mathrm{O}_{2}$. The percentage of $\mathrm{H}_{2} \mathrm{O}_{2}$ scavenging was calculated using the following equation:

$$
\text { \%inhibition }=\{(\text { Ao-As }) / \text { Ao }\} * 100
$$

Here, Ao is the absorbance of positive control and As is the absorbance of the sample.

The $\mathrm{IC}_{50}$ value is the concentration of the sample required to scavenge $50 \%$ of $\mathrm{H}_{2} \mathrm{O}_{2}$ free radicals and we calculated this from the plot of \% inhibition against the log concentration of sample extract.

\section{Ferric reducing antioxidant potential (FRAP) assay}

Ferric reducing activity of both plant extracts was measured according to a previously documented method [51]. Crude extracts $(100-500 \mu \mathrm{g})$ were added to $300 \mu \mathrm{l}$ of distilled water followed by $3 \mathrm{~mL}$ of FRAP reagent. The FRAP reagent was prepared by adding $300 \mathrm{mmol} / \mathrm{L}$ acetate buffer (pH 3.6), $10 \mathrm{mmol} / \mathrm{L} \quad$ 2,4,6-Tri(2-pyridyl)-s-triazine (TPTZ) in $40 \mathrm{mmol} / \mathrm{L} \mathrm{HCl}$ and $20 \mathrm{mmol} / \mathrm{L} \mathrm{FeCl}_{3} \cdot 6 \mathrm{H}_{2} \mathrm{O}$ at a ratio of 10:1:1. The absorbance was read at $593 \mathrm{~nm}$ after 4 min incubation at ambient temperature against a blank of distilled water. Results were expressed in mmol Fe (II)/ $\mathrm{g}$ of a sample using $\mathrm{FeSO}_{4} \cdot 7 \mathrm{H}_{2} \mathrm{O}$ standard curve.

\section{Anti-hemolytic activity assay}

The anti-hemolytic potential of both extracts was determined by the spectrophotometric procedure as described previously with few modifications [52]. Ten milliliters of blood from a healthy person was collected in EDTA vials (10\%) and centrifuged for $10 \mathrm{~min}$ at $3000 \mathrm{rpm}$. The supernatant was removed and the pellet was washed thrice with 0.2 M PBS ( $\mathrm{pH} 7.4$ ) and centrifuged for 10 $\mathrm{min}$ at $300 \mathrm{rpm}$ before re-suspending in saline solution $(0.9 \% \mathrm{NaCl}) .0 .4 \mathrm{~mL}$ of extracts $(125-1000 \mu \mathrm{g} / \mathrm{mL}$ in PBS) were dispensed to $0.4 \mathrm{~mL}$ of erythrocyte suspension and incubated at $37^{\circ} \mathrm{C}$ for $5 \mathrm{~min}$. Later, $0.2 \mathrm{~mL}$ of $\mathrm{H}_{2} \mathrm{O}_{2}$ $(0.82 \mathrm{M}, \mathrm{PBS})$ solution was added to the reaction mixture for inducing the membrane lipids' oxidative degeneration. The samples were again incubated at a temperature of $37^{\circ} \mathrm{C}$ at $120 \mathrm{rpm}$ for $3 \mathrm{~h}$. After incubation, the samples were subsequently centrifuged at 3000 rpm for $10 \mathrm{~min}$ and the absorbance of the supernatant was noted at $540 \mathrm{~nm}$. Relative hemolysis was assessed in comparison with the hemolysis in $\mathrm{H}_{2} \mathrm{O}_{2}$ treated negative control. In this experiment, L-ascorbic acid was used as the standard $(31.5-1000 \mu \mathrm{g} / \mathrm{mL})$ and the blank solution was prepared by adding $0.2 \mathrm{M}$ PBS and $0.82 \mathrm{M} \mathrm{H}_{2} \mathrm{O}_{2}$. Approval for this experiment was obtained from the Ethical Research Committee, Jashore University of Science and Technology, Jashore, Bangladesh.

\section{Antibacterial activity assay}

The antibacterial activity of each plant extract was evaluated using seven bacterial strains, of whichfive strains were Gram-negative (Escherichia coli, Escherichia coli O157: $H 7$, Salmonella enterica subsp. enterica; serotype: 
Typhi”, [query: all this is worded correctly?] Enterobacter cloacae and Salmonella enterica) and the other two were Gram-positive (Streptomyces aureus, Listeria monocytogenes). All these strains were collected from the Microbiology Department laboratory, Jashore University of Science and Technology. The inoculums were prepared using a nutrient broth medium, and Mueller Hinton $(\mathrm{MH})$ was used to grow the bacteria. Bacterial strains were gently swabbed over $\mathrm{MH}$ agar media by pouring $100 \mu \mathrm{l}$ of LB broth culture. Four holes were made in each petri dish by using the Bohrer method. And then four different doses of plant extract solution $(50,100$, 200 and $400 \mathrm{mg} / \mathrm{mL}$ ) were poured onto the petris dishes. After incubation lasting $24 \mathrm{~h}$ at $37^{\circ} \mathrm{C}$, the diameter zone of inhibition $(\mathrm{mm})$ was measured against the test organisms. The antimicrobial activity of four antibiotics $\mathrm{COL}^{25}$ (Colistin Sulfate- $25 \mu \mathrm{g} /$ disc), $\mathrm{NA}^{30}$ (Nalidixic acid-30 $\mu \mathrm{g} / \mathrm{disc}$ ), $\mathrm{C}^{30}$ (Chloramphenicol-30 $\mu \mathrm{g} / \mathrm{disc}$ ) and $\mathrm{E}^{15}$ (Erythromycin-15 $\mu \mathrm{g} / \mathrm{disc}$ ) was measured against three bacteria E. coli, E. coli O157:H7 and S. aureus. Another four antibiotics $\mathrm{AZM}^{30}$ (Azithromycin-30 $\mu \mathrm{g} /$ disc), $\mathrm{CAZ}^{30}$ (Ceftazimide-30 $\mu \mathrm{g} /$ disc), $\mathrm{VA}^{30}$ (Vancomycin$30 \mu \mathrm{g} / \mathrm{disc}$ ) and $\mathrm{AMP}^{25}$ (Ampicillin-25 $\mu \mathrm{g} / \mathrm{disc}$ ) were measured against four bacteria, namely S. typhi, E. cloacae, L. monocytogenes, and S. enterica. These were also assayed as positive control.

\section{Brine shrimp lethality assay}

The previous method was followed to determine brine shrimp lethality assay of both plant extracts [53]. Eggs of brine shrimp were hatched in an aquarium using $1 \mathrm{~L}$ of $1 \mathrm{M}$ sodium chloride brine solution ( $\mathrm{pH}$ 8.5). The eggs were incubated for $48 \mathrm{~h}$ under fluorescent light and after hatching the nauplii were transferred to test tubes. Ten couples were transferred to each tube. $1.5 \mathrm{~mL} \mathrm{NaCl}$ solution was added to each test tube. Plant extract solutions at five different concentrations $(62.5,125$, 250,500 and $1000 \mu \mathrm{g} / \mathrm{mL}$ ) were used for this assay. Test tubes later had $1 \mathrm{~mL}$ of $\mathrm{NaCl}$ solution added to them. 1\% DMSO served as the negative control and after $12 \mathrm{~h}$ of incubation a count of the dead nauplii was done. $\mathrm{LC}_{50}$ value is the concentration of the sample required to kill $50 \%$ of the brine shrimp population and this was calculated from the plot of \% inhibition against the log concentration of sample extract. According to Meyer et al., a $\mathrm{LC}_{50}$ value of less than $1 \mathrm{mg} / \mathrm{mL}$ is considered toxic while a $\mathrm{LC}_{50}$ value greater than $1 \mathrm{mg} / \mathrm{mL}$ is deemed to be non-toxic [54].

\section{Statistical analysis}

All statistical analyses were performed using GraphPad Prism 8.1.0 (Graph Pad Software, Inc., USA).
Variations between and within groups have been analyzed for statistical significance by standard parametric and nonparametric tests, as appropriate. Linear regression analysis was also used to calculate the $\mathrm{IC}_{50}$ values. $P<0.05$ was taken as a level of statistical significance in all tests. The results were expressed as mean \pm SEM (Standard Error of Mean).

\section{Results}

Total phenolic content (TPC) of both plants' methanol extract was extrapolated from the calibration curve (Fig. 1a). They were $36.625 \pm 0.551$ and $58.917 \pm 0.601 \mathrm{mg}$ Gallic acid equivalents/g dry plant material in $H$. littoralis and B. gymnorrhiza, respectively (Table 1 ).

Total flavonoid contents were extrapolated from the linear equation of quercetin standard curve (Fig. 1 b). TFC obtained for both methanol extracts of $H$. littoralis and B. mycorrhizae are $114.52 \pm 0.339$ and $77.21 \pm 0.016$ mg quercetin equivalent/g extract (Table 1).

The methanol extracts of B. gymnorrhiza and $H$. littoralis exhibited a concentration-dependent DPPH scavenging activity (Fig. 2a) with values for $\mathrm{IC}_{50}$ being $113.79 \pm 0.168 \mu \mathrm{g} / \mathrm{mL}$ and $121.23 \pm 0.321 \mu \mathrm{g} / \mathrm{mL}$, respectively (Table 1). The DPPH scavenging activity was less than that of $\mathrm{L}$-ascorbic acid ( $\mathrm{IC}_{50}$ $35.7 \pm 0.46 \mu \mathrm{g} / \mathrm{mL}$ ), which is similar to what Hwang et al. (2007) reported and the value was $30.06 \pm 0.42 \mu \mathrm{g} / \mathrm{mL}$ [55].

The ability of $B$. gymnorrhiza and $H$. littoralis to scavenge hydrogen peroxide is summarized in Table $1 . B$. gymnorrhiza leaf extract exhibited a concentrationdependent $\mathrm{H}_{2} \mathrm{O}_{2}$ scavenging activity (Fig. 2b) with $\mathrm{IC}_{50}$ of $112.91 \pm 0.164 \mu \mathrm{g} / \mathrm{mL}$. Similarly, H. littoralis leaves exhibited $50 \%$ inhibition at a concentration of $140.32 \pm$ $0.301 \mu \mathrm{g} / \mathrm{mL}$. The $\mathrm{IC}_{50}$ value of $\mathrm{L}$-ascorbic acid was $112.91 \pm 0.164 \mu \mathrm{g} / \mathrm{mL}$.

Ferric reducing antioxidant capacity was calculated from the linear equation obtained from the standard curve of $\mathrm{FeSO}_{4} \cdot 7 \mathrm{H}_{2} \mathrm{O}$ (Fig. 1c). In this study, methanol extracts of $B$. gymnorrhiza demonstrated a greater FRAP value $(193.97 \pm 0.508 \mathrm{mmol}$ equivalent of $\mathrm{Fe}$ (II)/gram sample) than $H$. littoralis $(101.11 \pm 0.418$ mmol equivalent of $\mathrm{Fe}$ (II)/gram sample) (Table 1). On the other hand, FRAP value for standard Lascorbic acid was found to be $36.78 \pm 0.263 \mathrm{mmol}$, which was equivalent to the $\mathrm{Fe}$ (II)/gram sample.

The anti-hemolytic activity of both methanol extracts was obtained from a concentration (125$1000 \mu \mathrm{g} / \mathrm{mL}$ ) dependent assay. The absorbance of $B$. gymnorrhiza treated samples ranged from 0.72-1.18 which is close to the absorbance obtained from samples treated with L-ascorbic (0.71-1.41). On the other hand, $H$. littoralis showed slightly low absorbance on a concentration-dependent assay (0.611.02). According to these results, B. gymnorrhiza and 


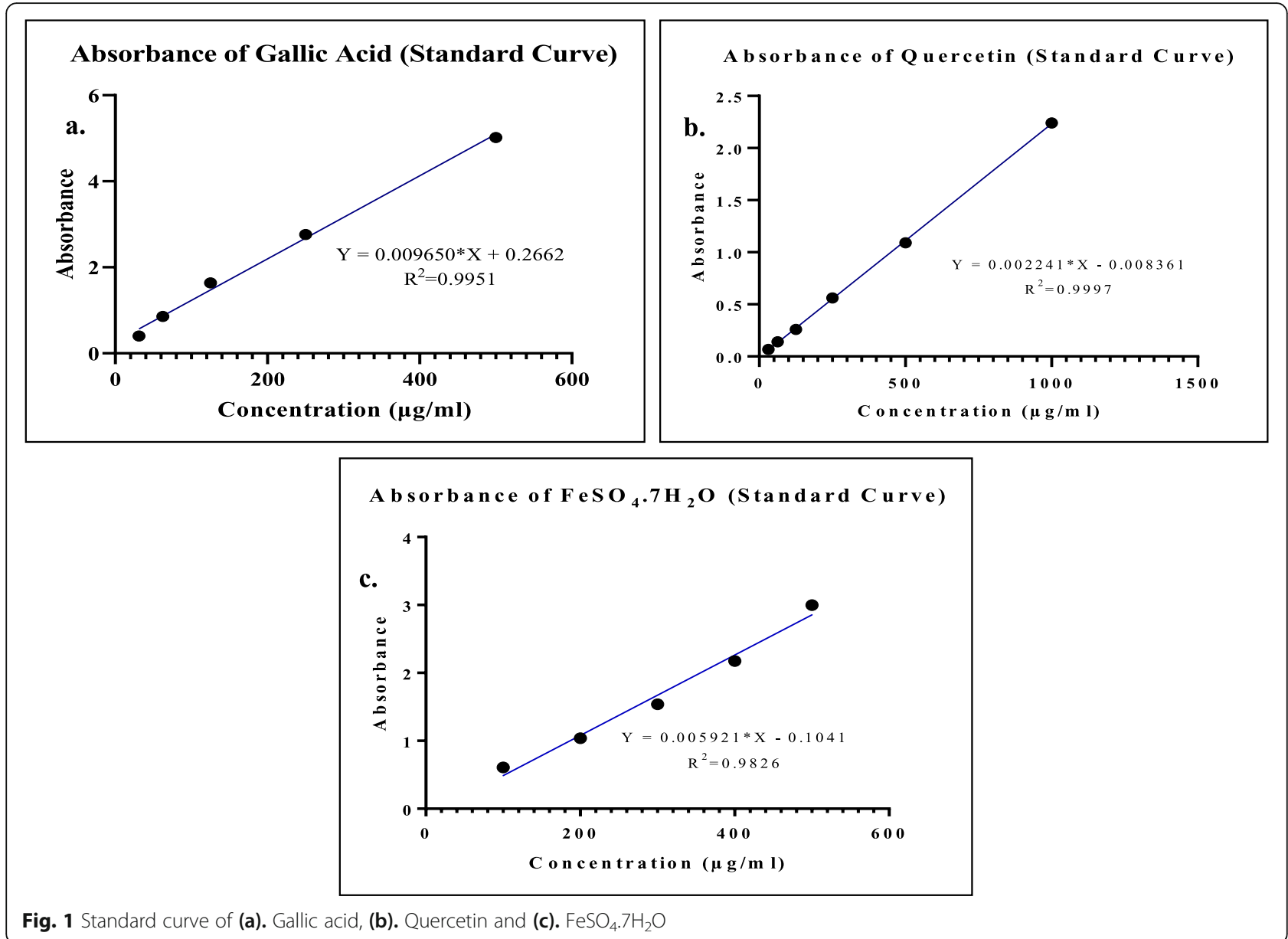

$H$. littoralis were reported to have $\mathrm{IC}_{50}$ values of $311.28 \pm 5.48$ and $526.90 \pm 25.85 \mu \mathrm{g} / \mathrm{mL}$, respectively. $\mathrm{L}$-ascorbic acid indicated an $\mathrm{IC}_{50}$ value of $282.14 \pm$ $6.96 \mu \mathrm{g} / \mathrm{mL}$. The results are summarized in Table 2 .

The antibacterial properties of methanol extract of B. gymnorrhiza and $H$. littoralis have shown activity against both Gram-positive and Gram-negative bacteria, with MICs of $10.3-20.1 \mathrm{mg} / \mathrm{mL}$ and $6.8-17.6$ $\mathrm{mg} / \mathrm{mL}$, respectively (Table 3 ). B. gymnorrhiza has demonstrated the most activity against $E$. cloacae $(20.1 \mathrm{mg} / \mathrm{mL})$ and E. coli O157:H7 $(18.8 \mathrm{mg} / \mathrm{mL})$ (Fig. 3a), while $H$. littoralis was highly lethal against $S$. enterica $(17.6 \mathrm{mg} / \mathrm{mL}$ ) (Fig. 3b). The positive control groups, on the other hand, showed growth inhibition against susceptible bacterial strains and were significant compared to the examined extracts. However, no inhibition zone was found in the negative control group.

Brine shrimp lethality assay of both plants extract was carried out in a concentration-dependent manner ranging from $62.5-1000 \mu \mathrm{g} / \mathrm{mL}$ (Fig. 4). The lethality concentration $\left(\mathrm{LC}_{50}\right)$ were within the $216.3-343.1 \mu \mathrm{g} / \mathrm{mL}$ range $\left(\operatorname{LogLC} C_{50}=2.335-2.535 \mu \mathrm{M}, \quad \mathrm{R}^{2}=0.9451\right)$ and $211.5-276.5 \mu \mathrm{g} / \mathrm{mL} \quad\left(\operatorname{LogLC} \mathrm{C}_{50}=2.325-2.442 \mu \mathrm{M}, \quad \mathrm{R}^{2}=\right.$ 0.9789 ) for both $H$. littoralis and B. gymnorrhiza, respectively (Table 4).

Table 1 Antioxidant properties of methanol leaf extract of selected mangrove plant species

\begin{tabular}{llllll}
\hline Tested materials & Total phenolic content ${ }^{\mathrm{a}}$ & Total Flavonoid content ${ }^{\mathrm{b}}$ & $\begin{array}{l}\mathrm{DPPH} \text { scavenging capacity } \\
\mathrm{IC}_{50}(\mu \mathrm{g} / \mathrm{mL})\end{array}$ & $\begin{array}{l}\mathrm{H}_{2} \mathrm{O}_{2} \text { scavenging capacity } \\
\mathrm{IC}_{50}(\mu \mathrm{\mu g} / \mathrm{mL})\end{array}$ & FRAP value $^{\mathrm{c}}$ \\
\hline B. gymnorrhiza & $58.917 \pm 0.601$ & $77.21 \pm 0.016$ & $113.79 \pm 0.168$ & $112.91 \pm 0.164$ & $193.97 \pm 0.508$ \\
H. littoralis & $36.625 \pm 0.551$ & $114.52 \pm 0.339$ & $121.23 \pm 0.321$ & $140.32 \pm 0.301$ & $101.11 \pm 0.418$ \\
L-ascorbic acid & - & - & $35.7 \pm 0.46$ & $51.80 \pm 0.143$ & $36.78 \pm 0.263$ \\
\hline
\end{tabular}

${ }^{\mathrm{a}} \mathrm{mg}$ galic acid equivalent (GAE)/g sample, ${ }^{\mathrm{b}} \mathrm{mg}$ quercetin equivalent $(\mathrm{QE}) / \mathrm{g}$ sample, ${ }^{\mathrm{c}} \mathrm{mmol} \mathrm{Fe}(\mathrm{II})$ equivalent/g sample. Values are mean \pm SEM $(n=3)$, Statistical significance $p<0.05$ 

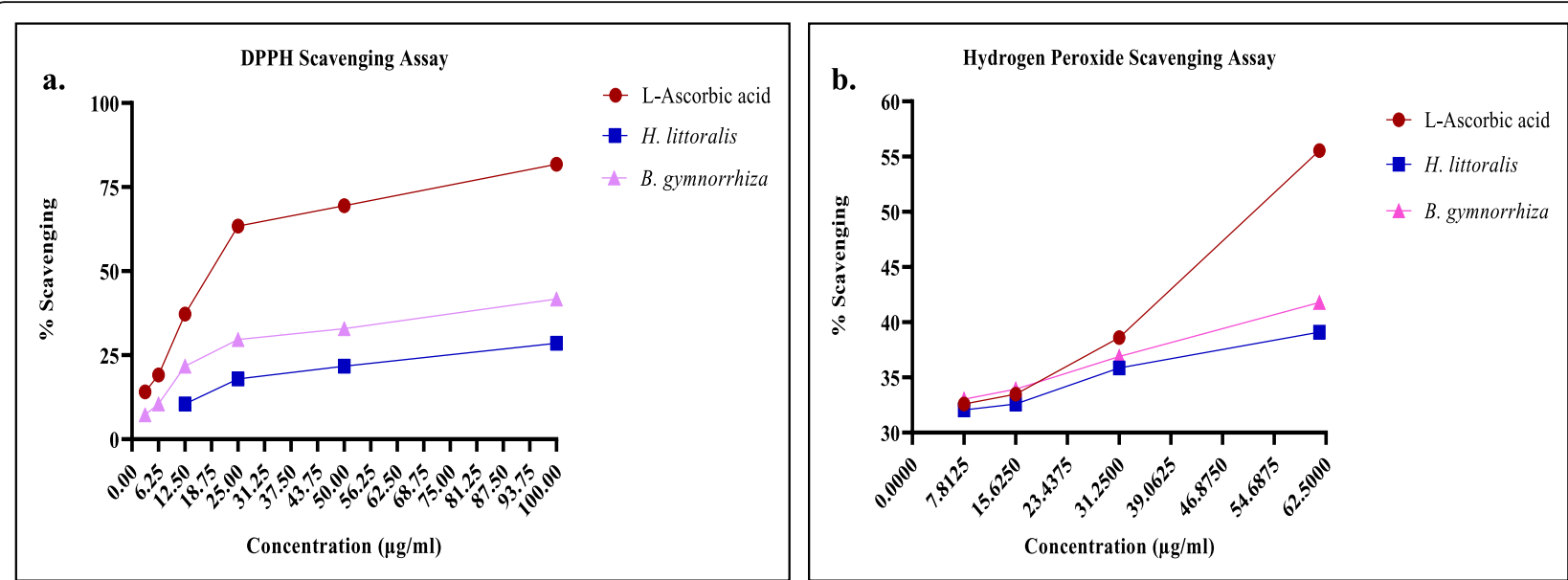

Fig. 2 (a) Concentration-dependent DPPH scavenging activity and (b) Concentration-dependent $\mathrm{H}_{2} \mathrm{O}_{2}$ scavenging activity of methanol extracts of B. gymnorrhiza and H. littoralis. Values are expressed as Mean \pm SEM $(n=3)$. L-ascorbic acid used as reference

\section{Discussion}

Plants consist of a large group of phenolic compounds, such as simple phenolics, phenolic acids, anthocyanins, hydroxycinnamic acid derivatives, and flavonoids. Because of their physiological functions such as free radical scavenging, anti-mutagenic, anticarcinogenic and anti-inflammatory effects, phenolic compounds of all classes have attracted much scientific attention [56-58]. According to Pietta (2000) and Soobrattee (2005), the antioxidant activity of phenol compounds largely occurs due to their redox properties which make them act as reducing agents, hydrogen donors, singlet oxygen quenchers and as well as potential metal chelators $[59,60]$. The hydroxyl group of phenolics and their derivatives mostly react with reactive oxygen and reactive nitrogen species in a termination reaction, which breaks the cycle of a generation of new radicals [61-65]. The interaction of the hydroxyl groups of phenolics with the $\pi$-electrons of the benzene ring gives the molecules special properties and allows them to generate free radicals where each radical is stabilized by delocalization. Formation of these relatively long-lived radicals is able to modify the radical-mediated oxidation process [66]. In this study, a considerably moderate level of phenolics was observed in the methanol extracts of B. gymnorrhiza and $H$. littoralis (Table 1).
The hydroxyl group of polyphenols is responsible for the scavenging of free radicals which also allows rapid screening of antioxidant activity. According to the results documented by Sur et al. (2016), the amount of phenolic content found in hydro-methanol extract of $B$. gymnorrhiza leaves was smaller than the phenolic content found in this study $(2.34 \pm 0.039 \mu \mathrm{g}$ Gallic acid equivalent/mg extract). Meanwhile the results of Nurjanah et al. (2016) reported $30.07 \mathrm{mg} \mathrm{GAE} / \mathrm{g}$ extract in methanol extract of B. gymnorrhiza $[67,68]$. On the other hand, this is the first report on the antioxidant activity of $H$. littoralis. Chemical structures of the total phenolic compounds are determined by the level of solvent polarity [69]. Polar solvents are highly capable of attracting phenolic compounds and the outcome is high phenolic activity. Ethanol has a higher polarity than methanol. Results reported by Haq et al. (2011) also showed higher phenolic content in ethanol extract when compared to methanol and chloroform [70].

The results of total flavonoid content (TFC) assay reported the highest presence of flavonols in $H$. littoralis compared to B. gymnorrhiza extract (Table 1). Flavonoids may have an additive effect on the endogenous scavenging compounds, which are subsequently depleted due to increased production of reactive oxygen species during an injury [71]. These compounds play an important role as plants secondary metabolites (flavones,

Table 2 Anti-hemolytic activity of methanol leaf extracts of selected mangrove plant species

\begin{tabular}{|c|c|c|c|c|c|c|c|}
\hline \multirow{2}{*}{$\begin{array}{l}\text { Tested } \\
\text { materials }\end{array}$} & \multirow{2}{*}{$\begin{array}{l}\text { Positive } \\
\text { control (A) }\end{array}$} & \multirow{2}{*}{$\begin{array}{l}\text { Negative } \\
\text { control (B) }\end{array}$} & \multicolumn{4}{|c|}{ Optical density at $540 \mathrm{~nm}$ at concentration $(\mu \mathrm{g} / \mathrm{mL})$} & \multirow{2}{*}{$\begin{array}{l}\mathrm{IC}_{50} \\
(\mu \mathrm{g} / \mathrm{mL})\end{array}$} \\
\hline & & & 125 & 250 & 500 & 1000 & \\
\hline B. gymnorriza & $1.45 \pm 0.005$ & $0.11 \pm 0.001$ & $0.72 \pm 0.01$ & $0.82 \pm 0.01$ & $0.94 \pm 0.01$ & $1.18 \pm 0.01$ & $311.29 \pm 5.48^{* *}$ \\
\hline H. littoralis & $1.45 \pm 0.005$ & $0.11 \pm 0.001$ & $0.61 \pm 0.01$ & $0.72 \pm 0.02$ & $0.88 \pm 0.02$ & $1.02 \pm 0.01$ & $526.90 \pm 25.85^{* *}$ \\
\hline L-ascorbic acid & $1.45 \pm 0.005$ & $0.11 \pm 0.001$ & $0.71 \pm 0.02$ & $0.76 \pm 0.01$ & $1.08 \pm 0.01$ & $1.41 \pm 0.01$ & $282.14 \pm 6.96^{* *}$ \\
\hline
\end{tabular}

All values represent mean $\pm \operatorname{SEM}(n=4)$, Statistical significance $(\boldsymbol{p}<\mathbf{0 . 0 0 5})$ is the same for values in the same column $\left(^{* *}\right)$. A; phosphate buffer saline treatment results in $0 \%$ hemolysis, $\mathbf{B}$; hydrogen peroxide replaced extract to serve as a negative control, treatment results with $100 \%$ hemolysis 
Table 3 In vitro activity of methanol extracts of B. gymnorrhiza and H. littoralis leaves against some opportunistic pathogens

\begin{tabular}{|c|c|c|c|c|c|c|c|c|}
\hline \multicolumn{9}{|c|}{ Diameter of the zone of inhibition (mm) } \\
\hline Tested materials & Concentration (mg/mL) & $\mathrm{EO}_{1}$ & $\mathrm{EO}_{2}$ & $\mathrm{EO}_{3}$ & $\mathrm{EO}_{4}$ & $\mathrm{EO}_{5}$ & $\mathrm{EO}_{6}$ & $\mathrm{EO}_{7}$ \\
\hline \multirow[t]{4}{*}{ B. gymnorrhiza } & 50 & $10.3 \pm 0.17$ & $12.3 \pm 0.33$ & $12.6 \pm 0.44$ & $12.1 \pm 0.17$ & $14.6 \pm 0.33$ & $10.6 \pm 0.33$ & $11.1 \pm 0.17$ \\
\hline & 100 & $11.5 \pm 0.29$ & $16.8 \pm 0.44$ & $15.3 \pm 0.33$ & $13.6 \pm 0.44$ & $16.0 \pm 0.58$ & $12.1 \pm 0.33$ & $11.8 \pm 0.33$ \\
\hline & 200 & $15.6 \pm 0.17$ & $17.5 \pm 0.29$ & $17.3 \pm 0.17$ & $15.6 \pm 0.33$ & $17.8 \pm 0.17$ & $15.6 \pm 0.33$ & $14.1 \pm 0.17$ \\
\hline & 400 & $18.6 \pm 0.33$ & $18.8 \pm 0.17$ & $20.3 \pm 0.72$ & $18.3 \pm 0.33$ & $20.1 \pm 0.60$ & $18.1 \pm 0.44$ & $18.3 \pm 0.44$ \\
\hline \multirow[t]{4}{*}{ H. littoralis } & 50 & $8.1 \pm 0.17$ & $9.8 \pm 0.44$ & $8.1 \pm 0.17$ & $10.1 \pm 0.17$ & $6.8 \pm 0.17$ & $8.1 \pm 0.17$ & $8.5 \pm 0.29$ \\
\hline & 100 & $10.1 \pm 0.17$ & $11.8 \pm 0.44$ & $11.8 \pm 0.44$ & $12.6 \pm 0.33$ & $8.3 \pm 0.17$ & $12.5 \pm 0.29$ & $10.3 \pm 0.17$ \\
\hline & 200 & $10.8 \pm 0.17$ & $13.3 \pm 0.33$ & $14.6 \pm 0.33$ & $13.1 \pm 0.60$ & $10.8 \pm 0.44$ & $14.1 \pm 0.33$ & $12.8 \pm 0.44$ \\
\hline & 400 & $14.1 \pm 0.17$ & $16.1 \pm 0.17$ & $15.3 \pm 0.33$ & $15.8 \pm 0.44$ & $14.6 \pm 0.33$ & $15.3 \pm 0.44$ & $17.6 \pm 0.44$ \\
\hline$N A^{30}$ & - & $20.3 \pm 0.17$ & $23.1 \pm 0.17$ & - & $23.6 \pm 0.17$ & - & - & - \\
\hline$C^{30}$ & - & $31.0 \pm 0.50$ & $27.8 \pm 0.44$ & - & $29.3 \pm 0.33$ & - & - & - \\
\hline$A Z M^{30}$ & - & - & - & $16.1 \pm 0.17$ & - & $35.8 \pm 0.44$ & $17.0 \pm 0.58$ & $16.6 \pm 0.33$ \\
\hline$C A Z^{30}$ & - & - & - & $17.6 \pm 0.33$ & - & $19.8 \pm 0.17$ & $21.1 \pm 0.60$ & $18.1 \pm 0.44$ \\
\hline$V A^{30}$ & - & - & - & - & - & $16.3 \pm 0.67$ & - & - \\
\hline $\mathrm{AMP}^{35}$ & - & - & - & $23.1 \pm 0.60$ & - & $15.3 \pm 0.17$ & $13.8 \pm 0.44$ & $21.1 \pm 0.60$ \\
\hline Negative control (methanol) & - & - & - & - & - & - & - & - \\
\hline
\end{tabular}

All the data are means of three replicates $(n=3) \pm \mathrm{SEM},{ }^{* *} \mathrm{EO}=$ Experimental Organism; $\mathrm{EO}_{1}=E . \mathrm{coli}_{,} \mathrm{EO}_{2}=\mathrm{E} . \mathrm{coli} \mathrm{O} 157: \mathrm{H7}, \mathrm{EO}_{3}=S$. typhi, $\mathrm{EO}_{4}=\mathrm{S}$. aureus, $\mathrm{EO}_{5}=E$ .cloacae, $\mathrm{EO}_{6}=L$. monocytogens, $\mathrm{EO}_{7}=S$. enterica. $\mathrm{COL}^{25}$ and $\mathrm{E}^{15}$ showed no zone of inhibition in this experiment

flavanols, and condensed tannins). Their antioxidant activity depends on the concentration of free $\mathrm{OH}$ groups, especially 3-OH. Flavonoids stabilize the reactive oxygen species by reacting with the reactive compound of free radicals. The high reactivity of the hydroxyl group of the flavonoids inactivates the free radicals [72]. It has both in vitro and in vivo antioxidant activity characteristics $[73,74]$. Sur et al. (2016) reported $5.20 \pm 0.115 \mu \mathrm{g}$ quercetin equivalent/mg hydro-methanol extract of $B$. gymnorrhiza which is significantly smaller than our study's finding. The smaller quantity might have resulted due to the higher concentration of free $\mathrm{OH}^{-}$radicals of hydro-methanol extract in the previous study [67]. There are no previous reports of the flavonoid profile of $H$. littoralis.

DPPH scavenging assay is one of the best-known, accurate, and frequently employed methods which we used in this analysis. As shown in Table 1, the DPPH

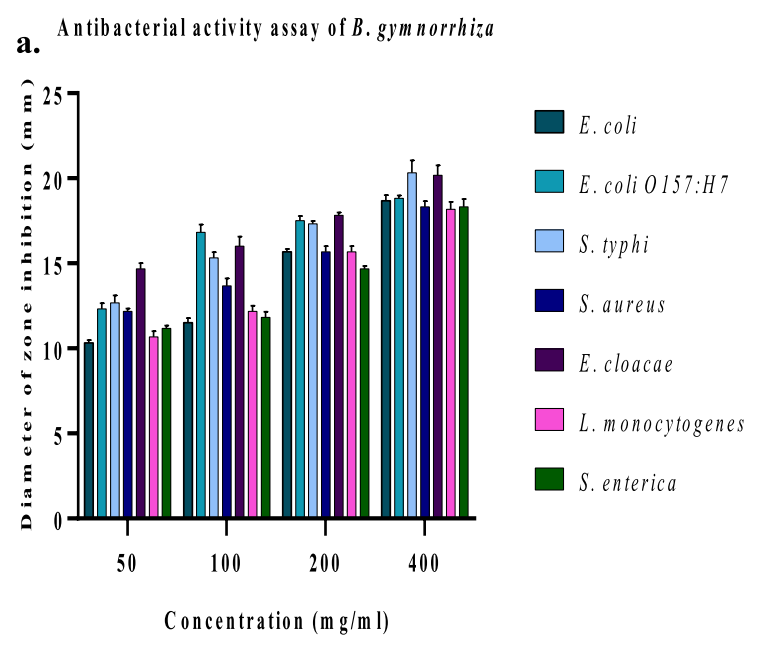

b. Antibacterial activity assay of $H$. littoralis

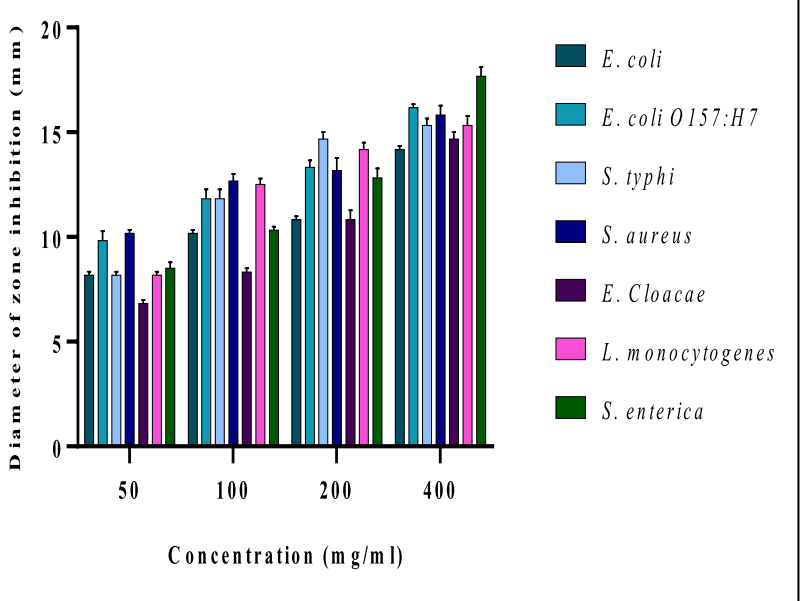

Fig. 3 Concentration-dependent antibacterial activity of (a) B. gymnorrhiza and (b) H. littoralis. Values are expressed as Mean \pm SEM ( $n=3$ ) 


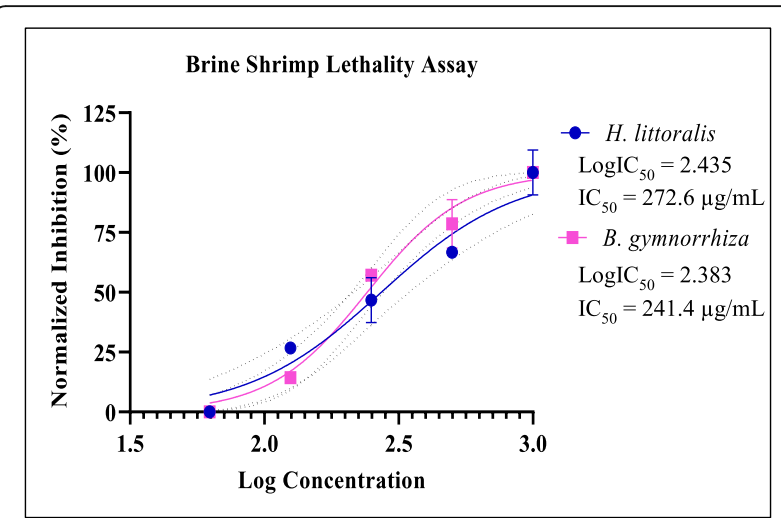

Fig. 4 Concentration-dependent brine shrimp lethality assay of methanol extracts of B. gymnorrhiza and H. littoralis. Values are expressed as Mean $\pm \operatorname{SEM}(n=3)$. Graph represents the percentage of inhibition against log of concentration

quenching capacity was found to be greater in B. gymnorrhiza than $H$. littoralis. One study, however, reported by Haq et al. (2011) showed slightly higher DPPH scavenging activity in ethanol extract of B. gymnorrhiza [70]. The difference may be caused by the presence of nonpolar compounds (fats and oils). Similarly, another study reported $96.8 \%$ radical scavenging at $100 \mu \mathrm{g} / \mathrm{mL}$ of ethanol extract of $H$. littoralis leaves, which is approximately 3.5 times higher than the result obtained in our study [39]. Furthermore, the results confirmed a significant correlation between total phenolic content and DPPH scavenging capacity. Sun and Ho (2005) reported a significant correlation between total phenolics and scavenging ability of buckwheat extracts on DPPH radicals [75]. It can be inferred from the results that both of our plants have stable DPPH radical scavenging potential by antioxidants compounds present in the extracts. However, L-ascorbic acid showed the highest DPPH radicals scavenging with $\mathrm{IC}_{50}$ of $35.7 \pm 0.46 \mu \mathrm{g} / \mathrm{mL}$.

Hydroxyl radical $\left(\mathrm{OH}^{\circ}\right)$ is the most reactive free radical which has the capacity to conjugate with nucleotides in DNA and cause strand breakage that may lead to carcinogenesis, mutagenesis, and cytotoxicity [76]. Of the two mangrove species, B. gymnorrhiza resulted in comparatively better $\mathrm{H}_{2} \mathrm{O}_{2}$ scavenging activity than $H$. littoralis (Table 1). According to the results, both plants have the potential to be cytotoxic and this means generating hydroxyl radicals in cells [77]. $\mathrm{H}_{2} \mathrm{O}_{2}$ scavenging results from the phenolic contents of the extracts which are able to donate electrons and thus form water [78]. These results also showed a significant relationship between $\mathrm{H}_{2} \mathrm{O}_{2}$ scavenging capacity and available total phenolic content. However, the $\mathrm{IC}_{50}$ value of $\mathrm{L}$-ascorbic acid was significantly better than both of the plant extracts, which may suggest a methanol extracts engaged in only weak antioxidant activity compared to the standard.

The FRAP assay measures the reducing potential of an antioxidant reacting with a ferric tripyridyltriazine $\left(\mathrm{Fe}_{3}{ }^{+}-\right.$ TPTZ) complex and produces a colored ferrous tripyridyltriazine $\left(\mathrm{Fe}_{2}{ }^{+}\right.$-TPTZ) [51]. Ferric reducing antioxidant properties are associated with the presence of compounds that cleave the free radical chain by donating a hydrogen atom $[79,80]$. The reducing properties are mostly linked with the presence of compounds which exert their action by breaking the free radical chain by releasing a hydrogen atom [79]. In the present study as shown in Fig. $3 \mathrm{~b}$, the absorbance of $\mathrm{Fe}_{2} \mathrm{SO}_{4} \cdot 7 \mathrm{H}_{2} \mathrm{O}$ standard curve clearly increased, due to the formation of the $\mathrm{Fe}^{2+}$-TPTZ complex with an increasing concentration. Highest $\mathrm{Fe}^{2+}$ quenching concentration was reported in B. gymnorrhiza extract. Results of the FRAP assay of both plants were significantly higher than the FRAP value of L-ascorbic acid $(36.78 \pm 0.263 \mathrm{mmol}$ equivalent of Fe (II)/gram sample). They show a strong relationship between total phenolic content and FRAP assay which is similar to the findings reported by Benzie and Szeto [81]. The redox potential of phenolic compounds allows them to act as hydrogen donors, reducing agents and singlet oxygen quenchers [80]. Such redox potential has played an important role in the determination of antioxidant potential. To date, no report on FRAP assay found for any of our experimental plants has been published. Consequently, it can be inferred from the results (Table 1), that both of our plants have higher $\mathrm{Fe}^{2+}$ quenching potential than the available commercial standard antioxidants.

Erythrocytes are the most abundant cells in the human body with their own replicative biological and morphological characteristics. The hemoglobins and polyunsaturated fatty acids (PUFA) mainly target the erythrocytes due to their redox-active oxygen transportation feature. As a result, hemolysis of erythrocyte membrane lipids and proteins are mutilated by oxidation. Such mutilation is accompanied by a number of factors such as deficiencies in erythrocyte antioxidant coordination, radiation, high quantity of transition metals, oxidative drugs, and hemoglobinopathies, etc. [78, 82]. Hemolysis occurs at a higher rate when erythrocytes are exposed to toxins like hydrogen peroxide [83]. In this experiment, we aimed at

Table 4 Cytotoxic activity of methanol leaf extract of selected mangrove plant species on brine shrimp nauplii

\begin{tabular}{lllll}
\hline Tested plants & Concentration tested $(\mu \mathrm{g} / \mathrm{mL})$ & $\operatorname{LogLC}_{50}(\mu \mathrm{M})$ & $\mathrm{LC} C_{50}(\mu \mathrm{g} / \mathrm{mL})$ & $95 \%$ confidence interval \\
\hline B. gymnorrhiza & $62.5,125,250,500,1000$ & 2.383 & 241.4 & $211.5-276.5$ \\
H. littoralis & $62.5,125,250,500,1000$ & 2.435 & 272.6 & $216.3-343.1$ \\
\hline
\end{tabular}


determining whether B. gymnorrhiza and $H$. littoralis prevented oxidative damage to the erythrocyte membrane or not. According to the results, B. gymnorrhiza exhibited higher anti-hemolytic activity with an $\mathrm{IC}_{50}$ value of $311.28 \pm 5.48 \mu \mathrm{g} / \mathrm{mL}$ while $H$. littoralis exhibited less significant activity with an $\mathrm{IC}_{50}$ value of $526.38 \pm$ $25.85 \mu \mathrm{g} / \mathrm{mL}$ (Table 2). The $\mathrm{IC}_{50}$ value of $\mathrm{L}$-ascorbic acid is $282.14 \pm 6.96 \mu \mathrm{g} / \mathrm{mL}$. In all cases, lysis of erythrocytes declined when an increase in the concentration of extracts and standards occurred. B. gymnorrhiza showed an effective hemolysis prevention activity. Furthermore, the results show a strong connection between total phenolic content and anti-hemolytic assay.

The obtained results suggest that both B. gymnorrhiza and $H$. littoralis are a potential source of broadspectrum antibacterial agents (Table 3). A more recent study on the antibacterial activity of n-hexane extract of B. gymnorrhiza leaf showed a significant level of inhibition against a large number of opportunistic bacterial species compared to the aqueous extract [84]. The antibacterial activity of the methanol extracts may be attributed to their total flavonoid content (TFC), which has been reported to be involved in inhibition of nucleic acid biosynthesis and also a number of other metabolic processes of microorganisms [85]. Flavonoids are also known to influence the permeability of both natural and synthetic membranes which might be a strong basis of the often mentioned bacteriocidal and antimycotic activity of flavonoids and propolis [86, 87].

Flavonoids are also known for their inhibitory activity against enzymes such as ATPase, phospholipase $\mathrm{A}_{2}$, prostaglandin cyclooxygenase and lipoxygenase [87]. One study has reported the ability of flavonoids and its derivatives to inhibit spore germination of plant pathogens [88]. Ohemeng et al. (1984) screened 14 derivatives of flavonoid for their inhibitory activity against Escherichia coli DNA gyrase, and for antibacterial activity against Staphylococcus epidermidis, S. aureus, E. coli, Salmonella typhimurium and Stenotrophomonas maltophilia [89]. The phenolic compounds with a C3 side chain also result in antimicrobial activity by lowering the level of oxidation [90]. The partially hydrophobic nature of polyphenols means they exhibit microbial lethality by inhibiting microbial hydrolytic enzymes (protease) or by inactivating microbial adhesins, cell envelop transport proteins and non-specific interaction with carbohydrates [91]. The polarity of methanol might have contributed to the activity of polyphenols thus resulting in microbial inhibition.

In the brine shrimp lethality assay, both plants showed a significant level of cytotoxicity (Table 4). The results of our experimental plants are significantly lower than the cytotoxicity of Vincristine sulfate $\left(\mathrm{LC}_{50}=0.91 \mu \mathrm{g} / \mathrm{mL}\right)$ reported by Ullah et al. [92]. According to Meyer et al., crude extracts of plants are considered toxic (active) if they have a $\mathrm{LC}_{50}$ value less than $1000 \mu \mathrm{g} / \mathrm{mL}$ [54]. Brine shrimp lethality assay permits a larger number of samples and dilutions by using a smaller quantity of extracts within a shorter time than using the original test vials [93]. Furthermore, it has been established that those crude extracts which exhibit significant cytotoxicity against $A$. salina larvae can be further recommended as a guide for pesticidal and anti-tumor compound detection. This is due to its simplicity, low cost and significant correlation with human solid tumor cell lines [84]. The in vitro antioxidant activity displayed by our experimental plants is a primary indicator of in vivo anti-tumor activity. However, there is a wide range of phytocompounds capable of exhibiting non-specific cytotoxic effects against $A$. salina larvae. On the other hand, anti-bacterial reported in this study represented a higher inhibitory zone at $500 \mathrm{mg} / \mathrm{mL}$ which is significantly higher than the $\mathrm{LC}_{50}$ value obtained from the cytotoxicity assay. Thus, further studies by isolating pure compounds via GCMS are required to identify the toxic compounds responsible for the resulting cytotoxicity.

\section{Conclusion}

It can be suggested here that methanol extracts of B. gymnorrhiza and $H$. littoralis leave exert a stabilizing effect on reactive oxidative species (ROS), inhibiting pathogenic bacterial strains and promoting cytotoxicity. In most cases, $B$. gymnorrhiza resulted in the highest yield of phenolic compounds than $H$. littoralis, which in contrast yielded higher flavonols. $B$. gymnorrhiza was more potent than $H$. littoralis in terms of antioxidant potential. However, the methanol extracts did not significantly reduce the free radicals under in vitro conditions. Both species have shown significant $\mathrm{Fe}^{2+}$ quenching, antibacterial and anti-hemolytic activity on human red blood cells (RBCs). Furthermore, this study paves the way to search for more effective antimicrobial compounds by isolating pure compounds and thereby developing novel antibiotic drugs against opportunistic bacterial species. Moreover, hepatoprotective, anti-hyperglycemic, anti-nociceptive, analgesic and anti-tumorigenic compounds from both of these mangrove species and can be isolated and administered for therapeutic approaches in vivo.

\footnotetext{
Acknowledgments

We would like to thank all the anonymous individuals who helped with this study. The authors also acknowledge the technical support provided by the laboratories of the following institutions: Nutrition and Food Technology, Microbiology, Pharmacy, Jashore University of Science and Technology.
}

\section{Author' contributions}

Md. AK and Md. Al conducted all the experiments. Mst. SS and SB carried out the antibacterial activity assay. Md. MI and Md. SR helped in the collection of plant material and executing of the experiments. Md. AK wrote the manuscript. Dr. NH has supervised the entire experiment and manuscript preparation. MJH, KKM, and Md. MR revised the manuscript and worked to improve the quality of the final manuscript. All authors read and approved the final manuscript. 


\section{Funding}

This experimental study has been funded by a grant provided by Jashore University of Science and Technology (Allocation No.: JUST/Reg./Gov. Project/ 1355/Research Fund/2017-1947).

\section{Availability of data and materials} Not applicable.

\section{Ethics approval and consent to participate}

This study was approved by the Ethical Research Committee of Jashore University of Science and Technology, Jashore-7408, Bangladesh.

\section{Consent for publication}

Not applicable.

\section{Competing interests}

The authors declare no conflict of interest.

\section{Author details}

${ }^{1}$ Department of Genetic Engineering and Biotechnology, Faculty of Biological Science and Technology, Jashore University of Science and Technology, Jashore, Bangladesh. ${ }^{2}$ Department of Genetic Engineering and Biotechnology, Shahjalal University of Science and Technology, Sylhet, Bangladesh. ${ }^{3}$ Department of Pharmacy, Faculty of Biological Science and Technology, Jashore University of Science and Technology, Jashore, Bangladesh. "Department of Genetic Engineering and Biotechnology, Mawlana Bhasani Science and Technology University, Tangail, Santosh, Bangladesh.

Received: 4 June 2019 Accepted: 27 January 2020 Published online: 07 February 2020

\section{References}

1. Mahmud SM, Mik J. Evaluation of antibacterial activity of indigenous medicinal plants in Bangladesh against some selected pathogenic strains. Pharmacologyonline. 2019;30(1):10-9.

2. Bandaranayake WM. Bioactivities, bioactive compounds and chemical constituents of mangrove plants. Wetl Ecol Manag. 2002;10(6):421-52.

3. Ghani A. Medicinal plants of Bangladesh with chemical constituents and uses. Nimtali, Dhaka: Asiatic Society of Bangladesh; 2003. p. 42-8.

4. Spalding M. The global distribution and status of mangrove ecosystems. Int News Lett Coastal Manage Intercoast Netw. 1997;1:20-1.

5. Barros L, Ferreira MJ, Queiros B, Ferreira IC, Baptista P. Total phenols, ascorbic acid, $\beta$-carotene and lycopene in Portuguese wild edible mushrooms and their antioxidant activities. Food Chem. 2007;103(2):413-9.

6. Gülçin I. Antioxidant and antiradical activities of L-carnitine. Life Sci. 2006;78(8):803-11.

7. Zhao X, Drlica K. Reactive oxygen species and the bacterial response to lethal stress. Curr Opin Microbiol. 2014;21:1-6.

8. Fang FC. Antimicrobial actions of reactive oxygen species. MBio. 2011;2(5).

9. Roginsky $V$, Lissi EA. Review of methods to determine chain-breaking antioxidant activity in food. Food Chem 2005 1;92(2):235-254.

10. Exarchou V, Nenadis N, Tsimidou M, Gerothanassis IP, Troganis A, Boskou D. Antioxidant activities and phenolic composition of extracts from Greek oregano, Greek sage, and summer savory. J Agric Food Chem. 2002;50(19):5294-9.

11. Witschi HP. Enhanced tumour development by butylated hydroxytoluene $(\mathrm{BHT})$ in the liver, lung and gastro-intestinal tract. Food Chem Toxicol. 1986; 24(10-11):1127-30.

12. Aggett PJ. Food additives. Issues Toxicol. 2018.

13. Gülçin I, Mshvildadze V, Gepdiremen A, Elias R. The antioxidant activity of a triterpenoid glycoside isolated from the berries of Hedera colchica: 3- O- ( $\beta$ d- glucopyranosyl)- hederagenin. Phytother Res. 2006;20(2):130-4.

14. Oktay M, Gülçin I, Küfrevioğlu Öl. Determination of in vitro antioxidant activity of fennel (Foeniculum vulgare) seed extracts. LWT-Food Sci Technol. 2003;36(2):263-71.

15. Baravalia $Y$, Vaghasiya $Y$, Chanda S. Brine shrimp cytotoxicity, antiinflammatory and analgesic properties of Woodfordia fruticosa Kurz flowers. Iran J Pharm Res. 2012;11(3):851-61.

16. Parra AL, Yhebra RS, Sardiñas IG, Buela LI. Comparative study of the assay of Artemia salina L. and the estimate of the medium lethal dose (LD50 value) in mice, to determine oral acute toxicity of plant extracts. Phytomedicine. 2001;8(5):395-400.
17. Manilal A, Sujith S, Kiran GS, Selvin J, Shakir C. Cytotoxic potentials of red alga, Laurencia brandenii collected from the Indian coast. Global J Pharmacol. 2009;3(2):90-4.

18. Sherman RE, Fahey TJ, Martinez P. Spatial patterns of biomass and aboveground net primary productivity in a mangrove ecosystem in the Dominican Republic. Ecosystems. 2003;6(4):384-98.

19. Vilarrúbia TV. Zonation pattern of an isolated mangrove community at playa Medina, Venezuela. Wetlands Ecol Manage. 2000;8(1):9-17.

20. M S D, Carlos J, Cerri CC, Dick WA, Lal R, Solismar Filho PV, Piccolo MC, Feigl BE. Organic matter dynamics and carbon sequestration rates for a tillage chronosequence in a Brazilian Oxisol. Soil Sci Soc Am J. 2001;65(5):1486-99.

21. Black CA. Soil fertility evaluation and control. U.K.: CRC Press; 2013.

22. Slattery WJ, Conyers MK, Aitken RL. Soil pH, aluminium, manganese and lime requirement. Soil Anal. 1999:103-28.

23. Joshi $\mathrm{H}$, Ghose M. Forest structure and species distribution along soil salinity and pH gradient in mangrove swamps of the Sundarbans. Trop Ecol. 2003:44(2):195-204.

24. McDonald KO, Webber DF, Webber MK. Mangrove forest structure under varying envrionmental conditions. Bull Mar Sci. 2003;73(2):491-505.

25. Krauss KW, Lovelock CE, McKee KL, López-Hoffman L, Ewe SM, Sousa WP. Environmentaldrivers in mangrove establishment and early development: a review. Aquat Bot. 2008:89(2):105-27.

26. Elser JJ, Hamilton A. Stoichiometry and the new biology: the future is now. PLoS Biol. 2007:5(7):e181.

27. Zhou Y, Tang N, Huang L, Zhao Y, Tang X, Wang K. Effects of salt stress on plant growth, antioxidant capacity, glandular Trichome density, and volatile exudates of Schizonepeta tenuifolia Briq. Int J Mol Sci. 2018;19(1):252.

28. Allen JA, Duke NC. Bruguiera gymnorrhiza (large-leafed mangrove). Elevitch, CR Species Profiles for Pacific Island Agroforestry. Hōlualoa: Permanent Agriculture Resources (PAR); 2006.

29. Bamroongrugsa N. Bioactive substances from the mangrove resource. Hat Yai, Songkhla: Prince of Songkla University; 1999.

30. Vadlapudi V. Phytochemical and antimicrobial investigation of mangrove plant Heritiera littoralis. Int J Chem Anal Sci. 2015:1-2

31. Patra JK, Thatoi HN. Metabolic diversity and bioactivity screening of mangrove plants: a review. Acta Physiol Plant. 2011;33(4):1051-61.

32. Lemmens RH, Wulijarni-Soetjipto N. Plant resources of South-East Asia. No. 3: Dye and tannin producing plants. Bogor, Indonesia: Prosea; 1991.

33. Sosef MS, Hong LT, Prawirohatmodjo S. Plant resources of South-East Asia. No. 5 (3): Timber trees: lesser-known timbers. Bogor, Indonesia: Prosea; 1998.

34. Nurjanah N, Jacoeb AM, Hidayat T, Shylina S. Bioactive compounds and antioxidant activity of lindur stem bark (Bruguiera gymnorrhiza). Int J Plant Sci Ecol. 2015;1(5):182-9.

35. Yoshio T, Kanako M, Hidako S, Toshiya M, Eiji H, Anki T, Takakazu HO. A new phenylpropanoidglycerol conjugate from Heritiera littoralis. Nat Med. 2000;54:22-5.

36. Miles DH, Lho DS, De la Cruz AA, Gomez ED, Weeks JA, Atwood JL. Toxicants from mangrove plant. 3. Heritol, a novel ichthyotoxin from the mangrove plant Heritiera littoralis. J Org Chem. 1987;52(13):2930-2.

37. Miles DH, Ly AM, Chittawong V, de la Cruz AA, Gomez ED. Toxicants from mangrove plants, VI. Heritonin, a new piscicide from the mangrove plant Heritiera littoralis. J Nat Prod. 1989;52(4):896-8.

38. Miles DH, Chittawong V, Lho DS, Payne AM, de la Cruz AA, Gomez ED, Weeks JA, Atwood JL. Toxicants from mangrove plants, VII. Vallapin and vallapianin, novel sesquiterpene lactones from the mangrove plant Heritiera littoralis. J Nat Prod. 1991;54(1):286-9.

39. Christopher R, Nyandoro SS, Chacha M, De Koning CB. A new cinnamoylglycoflavonoid, antimycobacterial and antioxidant constituents from Heritiera littoralis leaf extracts. Nat Prod Res. 2014;28(6):351-8.

40. Patra JK, Thatoi H. Anticancer activity and chromatography characterization of methanol extract of Heritiera fomes Buch. Ham., a mangrove plant from Bhitarkanika, India. Orient Pharm Exp Med. 2013;13(2):133-42.

41. Ali M, Nahar K, Sintaha M, Khaleque HN, Jahan Fl, Biswas KR, Swarna A, Monalisa MN, Jahan R, Rahmatullah M. An evaluation of antihyperglycemic and antinociceptive effects of methanol extract of Heritiera fomes Buch.-ham. (Sterculiaceae) barks in Swiss albino mice. Adv Nat Appl Sci. 2011;5(2):116-21.

42. Rahmatullah M, Md Imrul Sadeak S, Bachar SC, Tozammal Hossain M, Jahan $\mathrm{N}$, Chowdhury $\mathrm{MH}$, et al. brine shrimp toxicity study of different Bangladeshi medicinal plants. Adv Nat Appl Sci. 2010;4(2):163-73.

43. Hossain MA, Panthi S, Asadujjaman M, Khan SA, Ferdous F, Sadhu SK. Phytochemical and pharmacological assessment of the ethanol leaves extract of Heritiera fomes Buch. Ham.(FamilySterculiaceae). J Porphyrins Phthalocyanines. 2013;2:95-101. 
44. Wangensteen H, Dang HC, Uddin SJ, Alamgir M, Malterud KE. Antioxidant and antimicrobial effects of the mangrove tree Heritiera fomes. Nat Prod Commun. 2009;4(3) 1934578X0900400311.

45. Blainski A, Lopes G, de Mello J. Application and analysis of the folin ciocalteu method for the determination of the total phenolic content from Limonium brasiliense L. Molecules. 2013;18(6):6852-65.

46. Singleton VL, Rossi JA. Colorimetry of total phenolics with phosphomolybdicphosphotungstic acid reagents. Am J Enol Vitic. 1965;16(3):144-58.

47. Chang CC, Yang MH, Wen HM, Chern JC. Estimation of total flavonoid content in propolis by two complementary colorimetric methods. J Food Drug Anal. 2002;10(3):178-82.

48. Mihai CM, Mărghitaş LA, Bobiş $O$, Dezmirean D, Tămaş M. Estimation of flavonoid content in propolis by two different colorimetric methods. Sci Papers Anim Sci Biotechnologies. 2010;43(1):407-10.

49. Sánchez- Moreno C, Larrauri JA, Saura- Calixto F. A procedure to measure the antiradical efficiency of polyphenols. J Sci Food Agric. 1998;76(2):270-6.

50. Ruch RJ, Cheng SJ, Klaunig JE. Prevention of cytotoxicity and inhibition of intercellular communication by antioxidant catechins isolated from Chinese green tea. Carcinog. 1989;10:1003-8.

51. Benzie IF, Strain JJ. The ferric reducing ability of plasma (FRAP) as a measure of "antioxidant power": the FRAP assay. Anal Biochem. 1996;239(1):70-6

52. Yang ZG, Sun HX, Fang WH. Haemolytic activities and adjuvant effect of Astragalus membranaceus saponins (AMS) on the immune responses to ovalbumin in mice. Vaccine. 2005;23(44):5196-203.

53. Harwig J, Scott PM. Brine shrimp (Artemia salina L.) larvae as a screening system for fungal toxins. Appl Microbiol. 1971;21:1011-6.

54. Meyer BN, Ferrigni NR, Putnam JE, Jacobsen LB, Nichols DJ, McLaughlin JL. Brine shrimp: a convenient general bioassay for active plant constituents. Planta Med. 1982:45(05):31-4

55. Hwang IG, Woo KS, Kim DJ, Hong JT, Hwang BY, Lee YR, Jeong HS. Isolation and identification of an antioxidant substance from heated garlic (Allium sativum L.). Food Sci Biotechnol. 2007;16(6):963-6.

56. Manthey JA, Guthrie N, Grohmann K. Biological properties of citrus flavonoids pertaining to cancer and inflammation. Curr Med Chem. 2001;8(2):135-53.

57. Bandonienè D, Murkovic M. On-line HPLC-DPPH screening method for evaluation of radical scavenging phenols extracted from apples (Malus domestica L.). J Agric Food Chem. 2002;50(9):2482-7.

58. Kaur C, Kapoor HC. Anti- oxidant activity and total phenolic content of some Asian vegetables. Int J Food Sci Technol. 2002;37(2):153-61.

59. Pietta PG. Flavonoids as antioxidants. J Nat Prod. 2000;63(7):1035-42.

60. Soobrattee MA, Neergheen VS, Luximon-Ramma A, Aruoma Ol, Bahorun T. Phenolics as potential antioxidant therapeutic agents: mechanism and actions. Mutat Res Fundam Mol Mech Mutagen. 2005;579(1-2):200-13.

61. Valentão P, Fernandes E, Carvalho F, Andrade PB, Seabra RM, Bastos ML. Hydroxyl radical and hypochlorous acid scavenging activity of small centaury (Centaurium erythraea) infusion. A comparative study with green tea (Camellia sinensis). Phytomedicine. 2003;10(6-7):517-22.

62. Valentão P, Fernandes E, Carvalho F, Andrade PB, Seabra RM, Bastos ML. Antioxidative properties of cardoon (Cynara cardunculus $\mathrm{L}$ ) infusion against superoxide radical, hydroxyl radical, and hypochlorous acid. J Agric Food Chem. 2002;50(17):4989-93.

63. Heim KE, Tagliaferro AR, Bobilya DJ. Flavonoid antioxidants: chemistry, metabolism and structure-activity relationships. J Nutr Biochem. 2002;13(10):572-84.

64. Payá M, Halliwell B, Hoult JR. Interactions of a series of coumarins with reactive oxygen species: scavenging of superoxide, hypochlorous acid and hydroxyl radicals. Biochem Pharmacol. 1992:44(2):205-14.

65. Choi HR, Choi JS, Han YN, Bae SJ, Chung HY. Peroxynitrite scavenging activity of herb extracts. Phytother Res. 2002;16(4):364-7.

66. Parr AJ, Bolwell GP. Phenols in the plant and in man. The potential for possible nutritional enhancement of the diet by modifying the phenols content or profile. J Sci Food Agric. 2000;80(7):985-1012.

67. Sur TK, Hazra A, Hazra AK, Bhattacharyya D. Antioxidant and hepatoprotective properties of Indian Sunderban mangrove Bruguiera gymnorrhiza L. leave. J Basic Clin Pharm. 2016;7(3):75-9.

68. Nurjanah N, Jacoeb AM, Hidayat T, Hazar S, Nugraha R. Antioxidant activity, total phenol content, and bioactive components of lindur leave (Bruguierra gymnorrhiza). Am J Food Sci Health. 2016;2(4):65-70.

69. Harborne JB. In: Padmawinata K, Soediro I, editors. Metode Fitokimia: Penuntun Cara Menganalisis Tumbuhan. Bandung: Penerjemah; 1987. p. 1-99.

70. Haq M, Sani W, Hossain AB, Taha RM, Monneruzzaman KM. Total phenolic contents, antioxidant and antimicrobial activities of Bruguiera gymnorrhiza. J Med Plants Res. 2011;5(17):4112-8.
71. Nijveldt RJ, Van Nood EL, Van Hoorn DE, Boelens PG, Van Norren K, Van Leeuwen PA. Flavonoids: a review of probable mechanisms of action and potential applications. Am J Clin Nutr. 2001;74(4):418-25.

72. Korkina LG, Ev IB A'. antioxidant and chelating properties of flavonoids. In: Advances in pharmacology, vol. Vol. 38: Academic Press; 1996. p. 151-63.

73. Geetha S, Ram MS, Mongia SS, Singh V, llavazhagan G, Sawhney RC. Evaluation of antioxidant activity of leaf extract of Seabuckthorn (Hippophae rhamnoides L.) on chromium (VI) induced oxidative stress in albino rats. J Ethnopharmacol. 2003;87(2-3):247-51.

74. Shimoi K, Masuda S, Shen B, Furugori M, Kinae N. Radioprotective effects of antioxidative plant flavonoids in mice. Mutat Res. 1996;350(1):153-61.

75. Sun T, Ho CT. Antioxidant activities of buckwheat extracts. Food Chem. 2005;90(4):743-9.

76. Boyer J, Liu RH. Apple phytochemicals and their health benefits. Nutr J. 2004;3(1):5.

77. Gülçin I, Huyut Z, Elmastaş M, Aboul-Enein HY. Radical scavenging and antioxidant activity of tannic acid. Arab J Chem. 2010;3(1):43-53.

78. Ebrahimzadeh MA, Nabavi SF, Nabavi SM. Antioxidant activities of methanol extract of Sambucus ebulus L. flower. Pak J Biol Sci. 2009;12(5):447.

79. Duh PD, Du PC, Yen GC. Action of methanolic extract of mung bean hulls as inhibitors of lipid peroxidation and non-lipid oxidative damage. Food Chem Toxicol. 1999;37(11):1055-61.

80. Rice-Evans C, Miller N, Paganga G. Antioxidant properties of phenolic compounds. Trends Plant Sci. 1997;2(4):152-9.

81. Benzie IF, Szeto YT. Total antioxidant capacity of teas by the ferric reducing/ antioxidant power assay. J Agric Food Chem. 1999:47(2):633-6.

82. Hamidi M, Tajerzadeh H. Carrier erythrocytes: an overview. Drug Deliv. 2003; 10(1):9-20.

83. Naim M, Gestetner B, Bondi A, Birk Y. Antioxidative and Antihemolytic activities of soybean Isoflavones. J Agric Food Chem. 1976;24:1174-7.

84. Mazid MA, Datta BK, Nahar L, Sarker SD. Assessment of anti-bacterial activity and brine shrimp toxicity of two Polygonum species. Ars Pharmaceutica. 2008:49(2):127-34

85. Cushnie TT, Lamb AJ. Antimicrobial activity of flavonoids. Int J Antimicrob Agents. 2005:26(5):343-56.

86. Rusznyák S, Szent-Gyorgyi A. Vitamin P: flavonols as vitamins. Nat. 1936;138.

87. Havsteen B. Flavonoids, a class of natural products of high pharmacological potency. Biochem Pharmacol. 1983;32(7):1141-8.

88. Harborne JB, Williams CA. Advances in flavonoid research since 1992. Phytochemistry. 2000;55(6):481-504

89. Öksüz S, Ayyildiz H, Johansson C. 6-Methoxylated and C-glycosyl flavonoids from Centaurea species. J Nat Prod. 1984;47(5):902-3.

90. Baba SA, Malik SA. Determination of total phenolic and flavonoid content, antimicrobial and antioxidant activity of a root extract of Arisaema jacquemontii Blume. J Taibah Univ Sci. 2015;9(4):449-54.

91. Pyla R, Kim TJ, Silva JL, Jung YS. Enhanced antimicrobial activity of starchbased film impregnated with thermally processed tannic acid, a strong antioxidant. Int J Food Microbiol. 2010;137(2-3):154-60.

92. Ullah MO, Haque M, Urmi KF, Abu AH, Anita ES, Begum M, et al. Antibacterial activity and brine shrimp lethality bioassay of methanolic extracts of fourteen different edible vegetables from Bangladesh. Asian Pac J Trop Biomed. 2013;3(1):1-7.

93. Sam TW. Toxicity testing using the brine shrimp Artemia salina. In: Colegate SM, Moluneux RJ, editors. Bioactive natural products. Detection, isolation and structural determination. Boca Raton: CRC Press; 1993. p. 441-56.

\section{Publisher's Note}

Springer Nature remains neutral with regard to jurisdictional claims in published maps and institutional affiliations. 